\title{
Spatial Analysis Of Agricultural Cultivation Area Based On Space Allocation In Gayo Lues District Spatial Planning, the Year 2012 - 2032
}

\author{
Abubakar Karim, Muhammad Rusdi, Manfarizah, Darusman, and Hifnalisa \\ Department of Soil Science, Faculty of Agriculture, Universitas Syiah Kuala \\ \{darusman@unsyiah.ac.id\}
}

\begin{abstract}
This study aimed to (1) analyze the needs and availability of cultivation space that has been allocated based on the population of Gayo Lues District until the year of 2033 and (2) analyze the suitability of cultivation space utilization patterns based on space allocation in the Gayo Lues District Spatial Plan. The research was done in Gayo Lues District, Aceh Province, from March to Oct. 2018. Gayo Lues is located at $03^{\circ} 40^{\prime} 26^{\prime \prime}-04^{\circ} 16^{\prime} 55^{\prime \prime} \mathrm{N}$ and $96^{\circ} 43^{\prime} 24^{\prime \prime}-97^{\circ} 55^{\prime} 24^{\prime \prime} \mathrm{E}$, with an area of 554,991 ha. Materials and methods used included various thematic maps and imagery of Landsat satellites in 2016. In addition to the field observations, a survey tool in the form of a global positioning system (GPS) was used, and Arc GIS 10.4 software was used for spatial data processing. The results showed the allocation of the cultivated area until the year 2032 was 160,017 ha. This area is sufficient for the increasing population up to 2032 of $1.69 \%$ annually. However, the used space was not so uniformly distributed that we still found three sub-districts were not yet fulfilled such as Blangkejeren, Blang Pegayon, and Putri Betung since 2016, and Kuta Panjang starting in 2020. Based on the analysis of existing land use, we found a deviation of $1,482.30$ ha of land use. Land use deviations occur in all subdistricts, but the most deviated one was in Blangkejaren District, Dabun Gelang and Putri Betung. The deviation occurred was mainly due to the development of Sere Wangi cultivation. Based on the agreeable forestry land (TGHK) criteria, we found the unused area of 37,000 ha of 160,017 ha, for cultivation. However, there is 50,000 ha outside the allocation of cultivation area could be used for cultivation land. It is suggested that the allocation of cultivation be revised before the year 2032 .
\end{abstract}

Keywords: Cultivation Space, Adequacy And Land Availability, Land Use Deviation

\section{Introduction}

District of Gayo Lues Spatial Planning (RTRW) is a legal provincial/district document that allocates various provincial/district plannings[1], for Aceh Province is Qanun Aceh Nomor 19 of 2013 and Gayo Lues it is found in Qanun Nomor 15 (2013).

Base on RTRW document of Gayo Lues District is 554.991 ha. This area had allocated on noncultivated area 394.974 ha $(71,17 \%)$ and the cultivated area had allocated 160.017 ha $(28,83 \%)$. The population of Gayo Lues d in 2016 was 89,500 people [4], spread out in 11 sub-districts and 145 villages (Table 1). 
Table 1. Allocation area, population and its density at each sub-district based on cultivation and no cultivation.

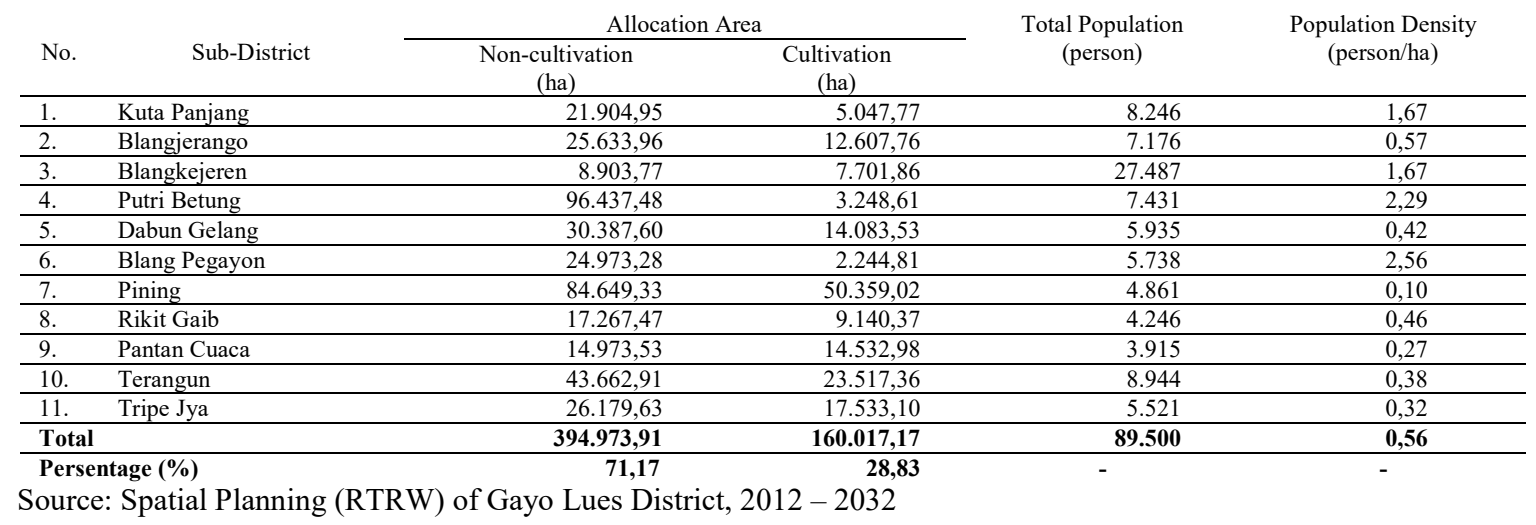

Field observation found that land use has deviated from the designated allocation of cultivation space. This is due to; (1) the community did not know clearly the boundaries of the cultivation area, (2) the land allocated for the cultivation area did not meet the needs of the farmers, both the extent and distribution, (3) the land ownership by the community for generations, because the criteria are determined as an area protected without being discussed with the concerned community, (4) farmers failed in utilizing the cultivation area properly to support their lives, (5) potential commodities were not planted according to land suitability classes and (6) commodities grown on land with suitable land suitability classes were not followed by the adoption of appropriate technology packages.

Based on the area of cultivation stated in the RTRW document and rapid development of the population of Gayo Lues, it is imperative that there is a deep evaluation of spatial adequacy based on the available area of cultivation in order Gayo Lues communities can carry out various economic activities now and future effectively and efficiently. The research objectives were to: (1) analyze the needs and availability of cultivated land that had been allocated based on the population of Gayo Lues District until the year 2032, and (2) analyze the suitability of cultivated utilization patterns based on space allocation in the Gayo Lues District Spatial Plan.

\section{Materials And Methods}

The study was conducted in Gayo Lues District, Aceh Province. Gayo Lues is located at: 03० 40'26 "- $04^{\circ}$ $16^{\prime} 55^{\prime \prime} \mathrm{N}$ and $96^{\circ} 43^{\prime} 24^{\prime \prime}-97^{\circ} 55^{\prime} 24^{\prime \prime}$ E, with an area of 554,991 ha. The study was conducted during March till Oct. 2018.

Maps of Gayo Lues' earth, administration, RTRW, slope, altitude, soil type with the scale of 1: 50,000 were used in this study [5], while data of population was taken from the national statistical office [4]. The global positioning system (GPS) was used during the ground check. A spatial data processing tool Arc GIS software was used (ESRI) for existing land use. Spatial analysis was carried out at the Remote Sensing and Cartography Lab., Fac. of Agriculture, Syiah Kuala University

The research methodology used was survey followed by descriptive analysis. The data used included primary and secondary data. Primary data was obtained through surveys and field observations, while secondary data from relevant agencies and literature studies. The population growth rate was calculated using the formula: $\{(\mathrm{CBR}-\mathrm{CDR}) / \mathrm{BR} \times 100 \%\}$. To predict the population up to 2032, population data of the year 2005 and 2016 was used. Allocation of cultivation areas refers to space patterns based on the Gayo Lues RTRWK. Existing land use was obtained from the analysis of Landsat imagery in 2016. TGHK maps were obtained based on Ministry Decree Number: (SK Menteri Pertanian Nomor 837/Kpts/Um/11/1980).

The first objective was conducted by calculating of land requirement using Seomerwoto formula (Seomarwoto, 1985), we then looked at the number of individual land needs by overlying with spatial planning of Gayo Lues district 2013-2032[3]. Furthermore, whether the land needs have been fulfilled according to the local area of the farmer (sub-district), then a comparison proceeded with the allocation of cultivation space that stipulated in the spatial planning of Gayo Lues district

The second objective was done by analyzing irregularities in land use. We overlapped between the map of the space pattern (cultivation area) and the existing land use map. If land use deviations occur because the allocation is not fulfilled (the results of objective 1), then we proceed overlapping between the existing land use map and a map of the allocation of the cultivation area. 


\section{Results And Discussion}

\subsection{Population Growth Analysis}

Based on population data from 2005 to 2016 and the projected population by 2032. Five-yearly population data for each sub-district, namely population data for 2016, 2020, 2025, 2030 and 2032 are presented in Table 2.

Table 2 shows that the population growth rate of Gayo Lues District is 1.69\% (medium criteria). Gayo Lues District is isolated and far from centers of economic growth. The distance from Blangkejeren City to the center of service and growth, namely: to the city of Banda Aceh with a distance of $475 \mathrm{~km}$, to the city of Takengon with a distance of $156 \mathrm{~km}$, to the city of Kuta Cane with a distance of $112 \mathrm{~km}$, to the city of Idi with a distance of about $205 \mathrm{~km}$, to the City of Blang Pidie with a distance of about $148 \mathrm{~km}$, and to the city of Medan, North Sumatra with a distance of $332 \mathrm{~km}$. All transportation routes (roads) to these cities are still not optimal.

Table 2. Population growth $(\mathrm{P} 0=2005 ; \mathrm{P} 32=2032)$, Number of $\mathrm{HH}$, and Farmers profile

\begin{tabular}{|c|c|c|c|c|c|c|c|c|c|c|c|}
\hline \multirow{2}{*}{$\begin{array}{l}\text { No } \\
\cdot\end{array}$} & \multirow{2}{*}{ Sub District } & \multicolumn{5}{|c|}{$\begin{array}{c}\text { Population and its Projection Growth } \\
\text { (persons) }\end{array}$} & \multirow{2}{*}{$\begin{array}{l}\text { Rat } \\
\text { e } \\
(\%)\end{array}$} & \multirow{2}{*}{$\begin{array}{l}\text { Criteri } \\
\text { a }\end{array}$} & \multirow{2}{*}{$\begin{array}{c}\text { Numbe } \\
\text { r of } \\
\text { HH, } \\
2016\end{array}$} & \multirow{2}{*}{$\begin{array}{c}\text { Number } \\
\text { People } \\
\text { per HH } \\
\text { (people), } \\
2016\end{array}$} & \multirow{2}{*}{$\begin{array}{c}\text { Number } \\
\text { of } \\
\text { Farmers } \\
\text { (people), } \\
2016\end{array}$} \\
\hline & & 2016 & $2020 *$ & $2025 *$ & 2030* & $2032 *$ & & & & & \\
\hline 1. & $\begin{array}{l}\text { Kuta } \\
\text { Panjang }\end{array}$ & 8.246 & 8.730 & 9.376 & $\begin{array}{r}10.06 \\
9 \\
\end{array}$ & $\begin{array}{r}10.36 \\
0 \\
\end{array}$ & 1,44 & $\mathrm{~S}$ & 2.617 & $\begin{array}{r}3,1 \\
5\end{array}$ & 4.602 \\
\hline 2. & $\begin{array}{l}\text { Blang } \\
\text { Jerango }\end{array}$ & 7.176 & 7.620 & 8.213 & 8.852 & 9.122 & 1,51 & $\mathrm{~S}$ & 2.299 & $\begin{array}{r}3,1 \\
2 \\
\end{array}$ & 4.134 \\
\hline 3. & $\begin{array}{l}\text { Blangkejera } \\
\mathrm{n}\end{array}$ & $\begin{array}{r}27.48 \\
7 \\
\end{array}$ & 30.112 & 33.748 & $\begin{array}{r}37.82 \\
3 \\
\end{array}$ & $\begin{array}{r}39.58 \\
7 \\
\end{array}$ & 2,31 & $\mathrm{~S}$ & 8.422 & $\begin{array}{r}3,2 \\
6 \\
\end{array}$ & $\begin{array}{r}12.53 \\
8 \\
\end{array}$ \\
\hline 4. & Putri Betung & 7.431 & 7.885 & 8.491 & 9.145 & 9.420 & 1,49 & $\mathrm{~S}$ & 2.521 & $\begin{array}{r}2,9 \\
5\end{array}$ & 5.431 \\
\hline 5 & $\begin{array}{l}\text { Dabun } \\
\text { Gelang }\end{array}$ & 5.935 & 6.650 & 7.667 & 8.838 & 9.356 & 2,89 & $\mathrm{~S}$ & 1.900 & $\begin{array}{r}3,1 \\
2 \\
\end{array}$ & 2.521 \\
\hline 6. & Blang Pegayon & 5.738 & 6.488 & 7.566 & 8.822 & 9.381 & 3,12 & $\mathrm{~S}$ & 1.725 & $\begin{array}{r}3,3 \\
3\end{array}$ & 3.593 \\
\hline 7. & Pining & 4.861 & 5.189 & 5.631 & 6.111 & 6.314 & 1,65 & $\mathrm{~S}$ & 1.475 & $\begin{array}{r}3,3 \\
0\end{array}$ & 3.399 \\
\hline 8. & Rikit Gaib & 4.246 & 4.238 & 4.227 & 4.217 & 4.213 & $\overline{-}$ & $\mathrm{R}$ & 1.362 & $\begin{array}{r}3,1 \\
2\end{array}$ & 2.483 \\
\hline 9. & $\begin{array}{l}\text { Pantan } \\
\text { Cuaca }\end{array}$ & 3.915 & 4.255 & 4.721 & 5.239 & 5.462 & 2,10 & $\mathrm{~S}$ & 1.231 & $\begin{array}{r}3,1 \\
8 \\
\end{array}$ & 2.639 \\
\hline 10. & Terangun & 8.944 & 9.481 & 10.198 & $\begin{array}{r}10.96 \\
9\end{array}$ & $\begin{array}{r}11.29 \\
3\end{array}$ & 1,47 & $\mathrm{~S}$ & 2.705 & $\begin{array}{r}3,3 \\
1\end{array}$ & 5.217 \\
\hline 11. & Tripe Jaya & 5.521 & 5.661 & 5.841 & 6.027 & 6.103 & 0,63 & $\mathrm{~S}$ & 1.754 & $\begin{array}{r}3,1 \\
5 \\
\end{array}$ & 3.698 \\
\hline Tot: & Average & $\begin{array}{r}89.50 \\
0\end{array}$ & 95.692 & $\begin{array}{r}104.03 \\
8\end{array}$ & 113.111 & 116.958 & 1,69 & $\mathbf{S}$ & $\begin{array}{r}28.01 \\
1\end{array}$ & $\begin{array}{r}3,2 \\
0\end{array}$ & $\begin{array}{r}50.45 \\
1\end{array}$ \\
\hline
\end{tabular}

Source: BPS District of Gayo Lues (2017); *Projection data by year. $\mathrm{S}=$ medium population growth, $\mathrm{R}=$ low population growth; $\mathrm{HH}=$ head of households

Table 2 also shows that the population growth rate per subdistrict includes the medium criteria, except the Rikit Gaib sub-district with low criteria (negative growth). This negative growth, if traced further, is caused by the movement of people to other sub-districts within the Gayo Lues District, especially the Pantan Cuaca SubDistrict and Blangkejeren sub-District and/or other sub-districts in other districts, especially Bener Meriah District, Southeast Aceh, and Central Aceh.

Table 2 shows that the number of heads of households (HH) of Gayo Lues District is 28,011 households and $56 \%(15,766$ households) of which are farmer households. This data also shows, even though the largest number of HH farmers in Blangkejeren Subdistrict, but from the proportion of HH the largest farmers remain in sub-districts that function as producers, such as Putri Betung, Pining, Pantan Cuaca, Tripe Jaya, and others.

\subsection{Space Allocation for Cultivation Area}

Data on the allocation of cultivated area based on the Gayo Lues Spatial Planning is presented in Table 3 and a map of the allocation of space for cultivation and non-cultivation areas is presented in Figure 1. 


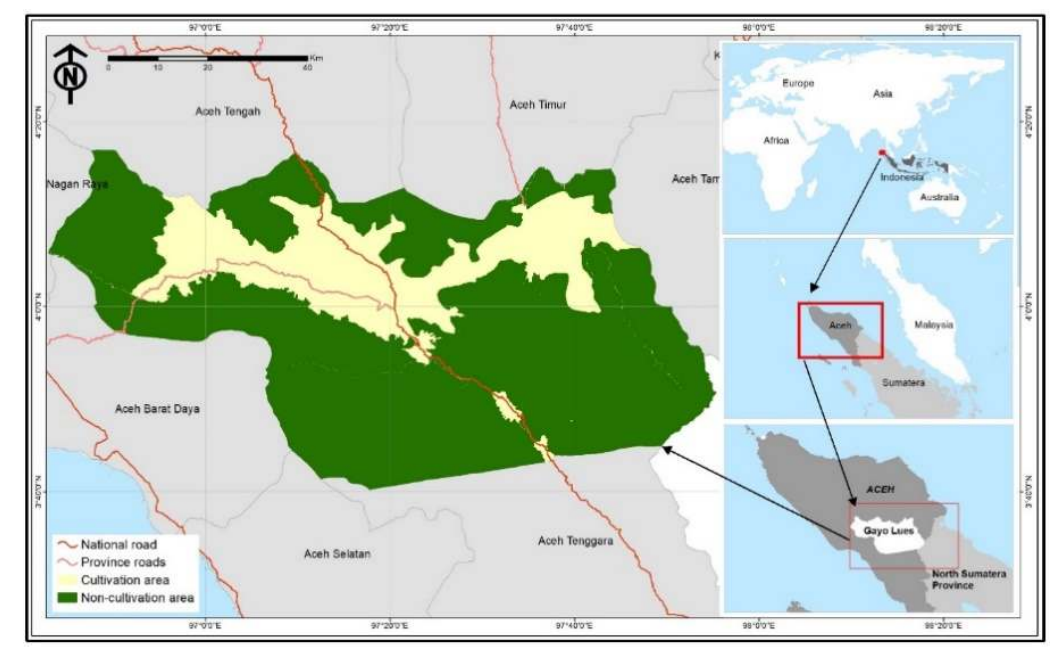

Figure 1. Map of allocation of cultivation and non-cultivation areas according to the Spacial Planning of Gayo Lues District (Qanun No. 15 of 2013)

Table 3. Plans for allocation of cultivated area (dry land and rice fields), non-cultivation areas, population profile, and profile of agricultural land according to BPS (2017) and Spacial Planning (RTRW) 2012 - 2032 of Gayo Lues District

\begin{tabular}{|c|c|c|c|c|c|c|c|c|c|c|c|c|}
\hline \multirow[b]{2}{*}{ No. } & \multirow[b]{2}{*}{ SubDistrict } & \multicolumn{3}{|c|}{ Cuktavation Area (ha) } & \multirow{2}{*}{$\frac{\text { NCA }}{\text { (ha) }}$} & \multirow{2}{*}{$\begin{array}{l}\text { Total } \\
\text { (ha) }\end{array}$} & \multirow{2}{*}{$\begin{array}{c}\text { PI } \\
\text { (peoples/km²) }\end{array}$} & \multirow{2}{*}{$\frac{\text { RatioP/A }}{\text { (people/km²) }}$} & \multirow{2}{*}{$\frac{\text { MRFI }}{\text { (ha) }}$} & \multirow{2}{*}{$\frac{\text { CRFI }}{\text { (ha) }}$} & \multirow{2}{*}{$\frac{\text { RFA }}{\text { (ha) }}$} & \multirow{2}{*}{$\begin{array}{r}\text { DLA } \\
\text { (ha) }\end{array}$} \\
\hline & & DL & WL & OU & & & & & & & & \\
\hline 1. & Kuta Panjang & $2.335,76$ & $1.181,50$ & $1.530,51$ & $21.904,95$ & $26.952,72$ & 30,59 & 163,35 & 150 & 972 & 1.122 & $2.335,04$ \\
\hline \multirow[t]{2}{*}{2.} & \multirow{2}{*}{ Blang Jerango } & \multirow[t]{2}{*}{$10.606,12$} & \multirow[t]{2}{*}{$1.966,14$} & \multirow[t]{2}{*}{358,50} & \multirow{2}{*}{\multicolumn{2}{|c|}{$38.241,72$}} & & & & & & $10.283,4$ \\
\hline & & & & & & & 18,76 & 56,92 & 100 & 1.205 & 1.305 & 8 \\
\hline \multirow[t]{2}{*}{3.} & \multirow{2}{*}{ Blangkejeran } & \multirow[t]{2}{*}{$5.501,68$} & \multirow[t]{2}{*}{714,80} & \multirow[t]{2}{*}{$1.485,38$} & \multirow[t]{2}{*}{$8.903,77$} & \multirow[t]{2}{*}{$16.605,63$} & 165,5 & & & & & \multirow[b]{2}{*}{$5.501,67$} \\
\hline & & & & & & & 2 & 356,88 & 423 & 930 & 1.353 & \\
\hline 4. & PutriBetung & $2.877,38$ & 182,06 & 189,17 & $96.437,48$ & $99,686,09$ & 7,45 & 228,72 & 99 & 232 & 331 & $2.877,38$ \\
\hline \multirow[t]{2}{*}{5.} & \multirow{2}{*}{$\begin{array}{l}\text { Dabun } \\
\text { Gelang }\end{array}$} & \multirow[t]{2}{*}{$12.746,77$} & \multirow[t]{2}{*}{454,61} & \multirow[t]{2}{*}{882,15} & \multirow[t]{2}{*}{$30.387,60$} & $44.471,13$ & & & & & & $12.746,7$ \\
\hline & & & & & & & 13,35 & 42,14 & 260 & 367 & 627 & 7 \\
\hline 6. & Blang & $1.277,49$ & 595,75 & 371,57 & $24.973,28$ & $27.218,09$ & & & & & & \\
\hline & Pegayon & & & & & & 21,08 & 255,59 & 290 & 256 & 546 & $1.277,49$ \\
\hline 7. & Pining & $48.091,70$ & $1.166,30$ & $1.101,02$ & $84.649,33$ & $135.008,35$ & & & & & & $48.091,7$ \\
\hline & Pining & & & & & & 3,60 & 9,65 & 45 & 151 & 196 & 0 \\
\hline 8. & RikitGaib & $8.220,18$ & 324,38 & 595.81 & $17.267,47$ & $26.407,84$ & 16,08 & 46,46 & 265 & 485 & 750 & $8.220,18$ \\
\hline 9. & & $14.027,80$ & 236,42 & 268,76 & $14.973,53$ & $29.506,51$ & & & & & & $14.027,8$ \\
\hline & Pantan Cuaca & & & & & & 13,27 & 26,94 & 140 & 285 & 425 & 0 \\
\hline 10. & & $17.731,14$ & 551,50 & $5.234,72$ & $43.662,91$ & $67.180,27$ & & & & & & $17.731,1$ \\
\hline & Terangun & & & & & & 13,31 & 38,03 & 230 & 446 & 676 & 4 \\
\hline 11. & & $16.749,29$ & 512,82 & 270,99 & $26.179,63$ & $43.712,73$ & & & & & & $16.749,2$ \\
\hline & Tripe Jaya & & & & & & 12,63 & 31,45 & 70 & 345 & 415 & 9 \\
\hline Total & & $139.841,94$ & $7.886,28$ & $12.288,95$ & $394.973,91$ & $554.991,08$ & 16,13 & 160.038 & 2.072 & 5.674 & 7.746 & $139.841,94$ \\
\hline Persen & se(\%) & 25,20 & 1,42 & 2,21 & 71,17 & 100,00 & - & - & - & - & - & - \\
\hline
\end{tabular}

Source : (BPS District of Gayo Lues, 2017); Spacial Planning (RTRW) of Gayo Lues District; (Qanun No. 15, the year 2013).

Note $: \mathrm{DL}=$ dry land, $\mathrm{WL}=$ Wet land, $\mathrm{OU}=$ Other use, and $\mathrm{NCA}=$ non cultivation area; $\mathrm{PI}=$ population intensity (people/km2), $\mathrm{P} / \mathrm{CA}=$ ratio of popuation- cultivation area (peopels $/ \mathrm{km} 2$ ), $\mathrm{MRFI}=$ modern rice field irrigation (ha), CRFI = conventional rice field irrigation (ha), RFA = rice field area (ha), DLA = dry land area (ha).

Table 3 and Figure 1 show that the cultivation area (DL, WL, and OU) of Gayo Lues District is 160,017.17 ha $(28.832 \%)$ and the area of non-cultivation areas (NCA) is 394,973.91 ha $(71,168 \%)$. If explored in more detail, the most extensive district of the cultivation area is Pining and Terangun sub-District and the narrowest is Blang Pegayon and Putri Betung Subdistrict. When viewed from the existing agricultural area, the allocation of cultivation space is in line with the direction of agricultural development in the Gayo Lues District, although it has not been followed by population distribution. Agricultural development areas are directed in the subDistricts of Pining, Terangun, Tripe Jaya, Pantan Cuaca, Dabun Gelang, and Blang Jerango. The plan of space allocation as a reference for regional development must be studied properly so that it can accommodate regional development and can provide benefits for the welfare of the community [8], [9] Furthermore, it is stated that the planned space allocation is carried out through the process and procedures for the preparation and determination of spatial plans based on the laws and regulations that apply and bind all parties [8].

The cultivation area is $160,017.17$ ha $(28.832 \%$ of the total area of Gayo Lues District $)$ and with a population of 89,500 people in 2016 , the area of cultivated land is sufficient to support the activities of the 
community of Gayo Lues District. This condition is suitable for the results of calculating the $\mathrm{Z}$ value of 0.74 ha/person.

Table 3 shows, the population density of all sub-districts including rare criteria, except Blangkejeren SubDistrict is classified as medium. The fewest population is Pining Subdistrict, which is around 3-4 people per $\mathrm{km} 2$, while the most densely populated is Blangkejeren subDistrict, which is $165-166$ people per km2. When associated with the availability of cultivated land, the most extensive area of cultivation is Pining Sub-district is 9-10 people per km2, while the narrowest subdistrict of agricultural land is Blangkejeren subDistrict, which is 442 - 443 people per $\mathrm{km} 2$ (around 0.23 ha per person). Based on this condition, it is necessary to make a policy for the movement of farmers from one sub-district to another or farmers not farming in the sub-district where they live.

\subsection{Farmer Growth Projections}

The number of farmers increase per year on average is 55,93\% until the year 2032. It means that more and more people depend on agriculture. This condition certainly encourages more extensive agricultural lands needed by farmers. The proportion of farmers in each sub-district is still higher than the people who have nonagricultural livelihoods, except the Blangkejeren and Dabun Gelang SubDistrict. This is understandable, because Blangkejeren subDistrict as the capital of Gayo Lues District is the center of government, and Dabun Gelang is a new growth area after the Gayo Lues was divided from Southeast Aceh District. In the District of Dabun Gelang as a new growth center, there are currently hospitals and military complexes, thus encouraging many people to live in the area and work with non-agricultural employment.

\subsection{Agricultural Land Needs}

Our results based on RTRW and number of the population until the year 2032 showed that cultivation area totaling of 160,017 has fulfilled people's needs. However, detail analyses based on sub-districts resulted that Blangkejeren, Putri Betung, and Blang Pegayon have not yet been fulfilled, and even Kuta Panjang will not be fulfilled since the year 2020 .

The results of the calculation of the adequacy of agricultural cultivation land (wetland and dry land) as stated in the Gayo Lues District Spatial Planning document Qanun Nomor 15 the year 2013 of each sub-district. It shows that based on the allocation of cultivated land, all sub-districts have been fulfilled, except Blangkejeren, sub-districts are not fulfilled, and neither is Kuta Panjang starting in 2020. Surplus and Deficit of required space allocation is given in Table 4.

Furthermore, for each subdistrict, population pressure is calculated on agricultural land and land carrying capacity to support farmers' activities. Calculation of population pressure using a formula Soemarwoto (1985) is presented in Table 4.

Table 4 shows that in general in Gayo Lues District there has been population pressure $(\mathrm{PP}>1)$ on agricultural land exceeding the carrying capacity of agricultural land ( $\mathrm{LCC}<1)$. This condition occurs in all sub-districts, except Putri Betung, Dabun Gelang, and Pining sub-district. The rate of land use change continues to occur, such as settlements shifting agricultural areas and agricultural land being pushed into forest areas, specially protected forests. The amount of land use change and population pressure on agricultural land results in the ability of the land to support life will change [11].

Specifically Putri Betung Subdistrict, in principle, agricultural land has been depressed by the population, but in this calculation, it is not visible. It is because that formula [ $\{\mathrm{fP} 0(1+\mathrm{r}) \mathrm{t}\} / \mathrm{L}]$ [10], it divided the total area in the relevant sub-district. Whereas if we look at the allocation of agricultural cultivation space, for the Putri Betung sub-district there are only around 3,200 ha for about 7,000 more residents. While the large area in Putri Betung Subdistrict is allocated for protected areas (LNP, Protection Forest, river border, lake border, etc.) around $96.74 \%$ of the total area of Putri Betung Sub-District (Table 4). Whereas Pining Subdistrict was allocated a cultivation area of 48,288 ha and farmers around $69.92 \%$ and Dabun Gelang with an area of 12,774 ha and farmers around $42.48 \%$.

\subsection{Analysis of Utilizing Spatial Area Allocation}

In this study, we used existing land as the cultivation space pattern. The farmers have carried out their cultivation for a long time, both those fostered by the Government and farming that have been carried out for generations. This farming business utilizes the appropriate space/ suitable for certain commodities according to the farmers' own assessment or the area that has been allocated by the government through the Gayo Lues District RTRW 2013 - 2032. In accordance with the Gayo Lues RTRWK 2012 - 2032, the cultivation area is allocated 160,017, 17 ha, which consists of dryland agriculture, wetland agriculture and other uses, and the non-cultivated area is allocated an area of 394,973.91 ha (Table 4). This classification should comply with its 
function criteria and is made in the form of land zoning based on its designation, including forestry, aquaculture, settlements, rice fields, industrial areas, plantations, tourist areas, and public facilities areas which can be interpreted as natural resource strategic plan [12]-[14]. The essence of the arrangement of agricultural cultivation space is to regulate the pattern of utilization and control of the cultivation space. The arrangement of cultivation space is crucial to be considered so that development actors understand the existence of an imbalance between the availability and needs of the regional space.

Table 4. Population Pressure of agricultural Land, Allocation of Cultivated Areas Available, Land Carrying Capacity of each Sub-District in Gayo Lues District 2012 - 2032

\begin{tabular}{|c|c|c|c|c|c|c|c|c|c|}
\hline No. & Sub District & $\frac{\text { Required }}{\text { (ha) }}$ & $\frac{\text { Allocation }}{\text { (ha) }}$ & $\frac{\text { Surplus }}{\text { (ha) }}$ & $\frac{\text { Deficit }}{\text { (ha) }}$ & $\begin{array}{c}\text { Population } \\
\text { Pressure }\end{array}$ & Criteria & $\begin{array}{l}\text { Carrying } \\
\text { Capacity }\end{array}$ & Criteria \\
\hline 1. & $\begin{array}{l}\text { Kuta } \\
\text { Panjang }\end{array}$ & 2.716 & 3.457 & 741 & - & 1,94 & $\mathrm{PP}>1$ & 0,52 & $\mathrm{LCC}<1$ \\
\hline 2. & $\begin{array}{l}\text { Blang } \\
\text { Jerango }\end{array}$ & 2.895 & 11.588 & 8.693 & - & 1,46 & $\mathrm{PP}>1$ & 0,69 & $\mathrm{LCC}<1$ \\
\hline 3. & Blangkejeran & 8.284 & 6.855 & - & 1.429 & 9,69 & $\mathrm{PP}>1$ & 0,10 & $\mathrm{LCC}<1$ \\
\hline 4. & Putri Betung & 3.853 & 3.208 & - & 645 & 0,75 & $\mathrm{PP}<1$ & 1,33 & $\mathrm{LCC}>1$ \\
\hline 5 & $\begin{array}{l}\text { Dabun } \\
\text { Gelang } \\
\end{array}$ & 1.868 & 12.774 & 10.906 & - & 0,82 & $\mathrm{PP}<1$ & 1,23 & $\mathrm{LCC}>1$ \\
\hline 6. & Blang Pegayon & 2.189 & 1.824 & - & 365 & 1,58 & $\mathrm{PP}>1$ & 0,63 & $\mathrm{LCC}<1$ \\
\hline 7. & Pining & 2.580 & 48.288 & 45,708 & - & 0,37 & $\mathrm{PP}<1$ & 2,70 & $\mathrm{LCC}>1$ \\
\hline 8. & Rikit Gaib & 1.787 & 8.970 & 7.183 & - & 1,29 & $\mathrm{PP}>1$ & 0,78 & $\mathrm{LCC}<1$ \\
\hline 9. & $\begin{array}{l}\text { Pantan } \\
\text { Cuaca }\end{array}$ & 2.006 & 14.453 & 12.447 & - & 1,32 & $\mathrm{PP}>1$ & 0,76 & $\mathrm{LCC}<1$ \\
\hline 10. & Terangun & 3.856 & 18.407 & 14.551 & - & 1,11 & $\mathrm{PP}>1$ & 0,90 & $\mathrm{LCC}<1$ \\
\hline 11. & Tripe Jaya & 2.772 & 17.164 & 14.392 & - & 1,21 & $\mathrm{PP}>1$ & 0,83 & $\mathrm{LCC}<1$ \\
\hline & Total & 36.829 & 147.588 & 111.000 & - & 1,28 & $\mathbf{T P}>1$ & $\mathbf{0 , 7 8}$ & $\mathrm{LCC}<1$ \\
\hline $\begin{array}{l}\text { Source } \\
\text { Note }\end{array}$ & $\begin{array}{l}: \mathrm{B} \\
: \mathrm{P}\end{array}$ & $\begin{array}{l}\text { PS District } \\
P=\text { popul }\end{array}$ & $\begin{array}{l}\text { f Gayo Lue } \\
\text { tion pressu }\end{array}$ & $\begin{array}{l}(2017) ; \mathrm{L} \\
e ; \mathrm{LCC}=\end{array}$ & $\begin{array}{l}\text { ta Anal } \\
\text { and cary }\end{array}$ & $\begin{array}{l}\text { ys }(2018) \\
\text { ig capasity }\end{array}$ & & & \\
\hline & $\begin{array}{l}\mathrm{PP}>1 \\
\mathrm{PP}<1 \\
\mathrm{LCC}>1 \\
\mathrm{LCC}<1\end{array}$ & $\begin{array}{l}\text { : Po } \\
\text { : Po } \\
\text { : hig } \\
\text { : loy }\end{array}$ & $\begin{array}{l}\text { ulation pr } \\
\text { ulation pr } \\
\text { land carr } \\
\text { land carry }\end{array}$ & $\begin{array}{l}\text { ssure hap } \\
\text { ssure not } \\
\text { ing capac } \\
\text { ng capac }\end{array}$ & $\begin{array}{l}\text { ened gre } \\
\text { ccurred } \\
\text { ty. } \\
\text { y. }\end{array}$ & $\begin{array}{l}\text { ter than cas } \\
\text { et, in other }\end{array}$ & $\begin{array}{l}\text { ying cap } \\
\text { words, la }\end{array}$ & $\begin{array}{l}\text { city } \\
\text { d has not }\end{array}$ & en used \\
\hline
\end{tabular}

The space allocation for the cultivation area turned out to have fulfilled the needs of the farming community until 2032, but in 2016 (after 3 years of preparation) it turned out that there were 3 subdistricts that did not fulfill their land allocation needs, namely Blangkejeren, Putri Betung, and Blang Pegayon.

\subsection{Use of Existing Land}

Existing land use was mapped through analysis of satellite imagery in 2016 . The results of this land use analysis were checked for correctness in the field. Existing land use maps are presented in Figure 2. Analysis of the existing land use map obtained by dry land (DL) is 127,419.32 ha (22.96\%), wet land (WL) as big as 5,507.21 $(0.99 \%)$, others use (OU) of $1,256.48(0.23 \%)$, protected area (PA or non cultivation area-NCA) of 420,833.05 ha $(75.82 \%)$, each spread in 11 sub-districts.

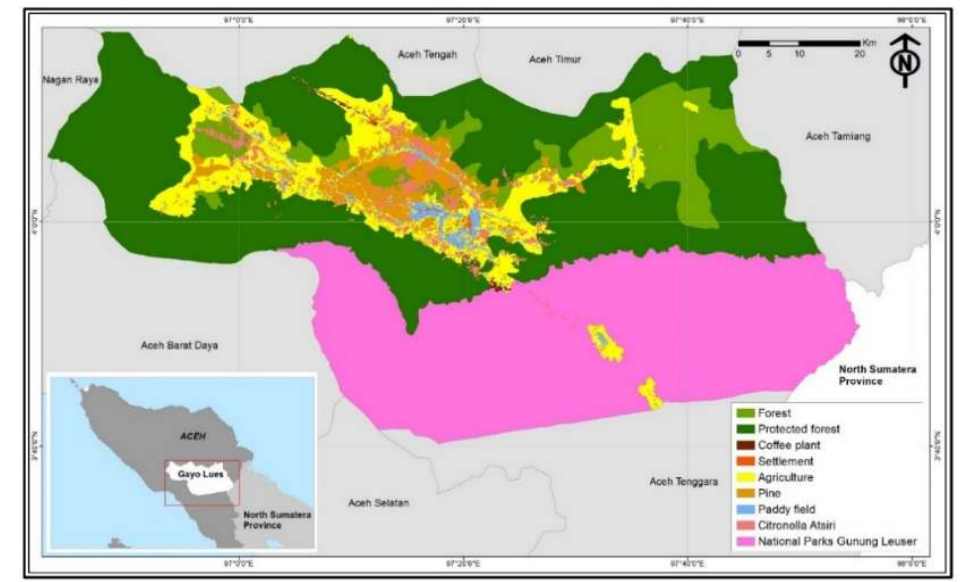

Figure 2. Existing land use maps from image analysis of Landsat satellite in 2016 Gayo Lues District 
When compared to Table 4 (allocation plan) and existing land use, we found some differences. The difference between; (1) the area of Gayo Lues District is about 25 ha. This condition is understandable and may occur due to shifting digitation; (2) differences in space allocation for cultivation areas, allocation of about $28.83 \%$, and existing calculations only around $24.72 \%$, there is a difference of $4.11 \%$; (3) there is a difference in the utilization of dry land allocation of $12,422.62 \mathrm{ha}$. General utilization remains in the area of each district, except in the District of Rikit Gaib the utilization has exceeded the allocation; (4) there is a difference in the utilization of the wetland allocation of 2,379.07 ha. In general, this condition is the same as the use of dry land; (5) there is a difference in the use of other use allocations of 11,032.47 and; (5) in the existing calculation, it turns out that the allocation of non-cultivation land is greater than 25,859.14 ha. This difference after the field check turns out to be true, that field conditions have occurred such as Figure 2.

\subsection{Land Use Deviation}

Land use irregularities are presented in Figure 3, and Table 5. Deviations are calculated for each sub-district and through unstructured interviews (discussions) with farmers, village officials, sub-districts, community leaders, answers are found.

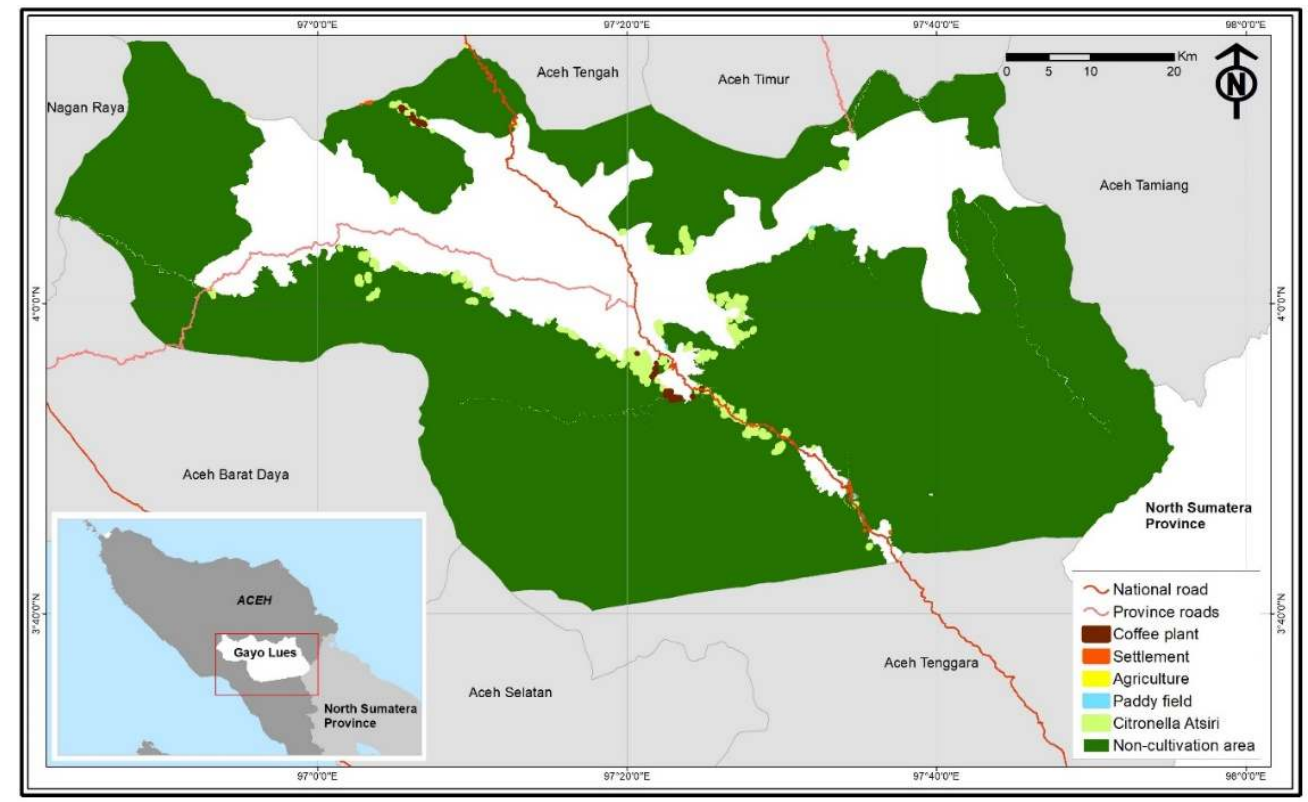

Figure 3. Map of Landuse Irregularities

Deviations in land use were analyzed, especially on lands allocated for non-cultivation areas, namely the LNP area and protected areas. There have been irregularities in the use of LNP land and protected forests in the amount of $1,482.30$ ha $(0.38 \%)$. When viewed from the percentage of irregularities in land use, we found it is still small (nonsignificant). Deviations in land use occurred in all districts, and the largest occurred in Blangkejeren (35.18\%), Putri Betung (16.28\%), and Dabun Gelang (21.83\%). The biggest irregularities in land use were used by the Sere Wangi community, which amounted to $91.02 \%$ and spread across all sub-districts. Even resident housings were built in the LNP area (Putri Betung) and protected areas (Pantan cuaca and Pining). In addition, we found also there are irregularities for coffee plantations (Blangkejeren and Pantan Cuaca) and rice fields.

Table 5. Irregularities in Landuse in Gayo Lues District

\begin{tabular}{|c|c|c|c|c|c|c|c|}
\hline \multirow[t]{2}{*}{ Sub-district } & \multirow[t]{2}{*}{ Area Status } & \multicolumn{6}{|c|}{ Deviated become (ha)* } \\
\hline & & CP & PRK & DLA & SWG & $\mathbf{R F}$ & Total \\
\hline Kuta Panjang & PA & - & - & - & 19,13 & - & 19,13 \\
\hline Blangjerango & PA & - & - & - & 52,34 & - & 52,34 \\
\hline \multirow[t]{2}{*}{ Blangkejeren } & PA & 31,99 & - & - & 420,71 & 0,20 & 452,90 \\
\hline & LNP & 38,08 & - & - & 30,43 & - & 68,51 \\
\hline Putri Betung & LNP & - & 13,64 & - & 220,23 & 7,40 & 241,27 \\
\hline Dabun Gelang & PA & - & - & - & 323,54 & - & 323,54 \\
\hline Blang Pegayon & PA & - & - & - & 36,13 & - & 36,13 \\
\hline Pining & PA & - & 0,11 & - & 44,31 & 1,43 & 45,85 \\
\hline Rikit Gaib & PA & - & - & - & 7,65 & - & 7,65 \\
\hline Pantan Cuaca & PA & 37,19 & 3,13 & 0,01 & 75,08 & - & 115,41 \\
\hline Terangun & PA & - & - & - & 111,24 & - & 111,24 \\
\hline
\end{tabular}




\begin{tabular}{|c|c|c|c|c|c|c|c|}
\hline Tripe Jaya & PA & - & - & - & 8,33 & - & 8,33 \\
\hline Total & & 107,26 & 16,88 & 0,01 & $1.349,12$ & 9,03 & $1.482,30$ \\
\hline
\end{tabular}

Source : Datal Analysis (2018)

Note* $: \mathrm{PA}=$ protected area, $\mathrm{LNP}=$ Leuser National Park, $\mathrm{CP}=$ Coffee plantation, $\mathrm{RA}=$ residence area,DLA

$=$ dry land agriculture, $\mathrm{SWG}=$ sere wangi gardening, $\mathrm{RF}=$ rice field

\subsection{Other Cultivation Areas that Can Be Utilized}

Cultivation areas that have the potential to still be utilized outside the allocation of agricultural cultivation space are done by overlaying the map of the cultivation area and the agreeable forestry land (TGHK) map. The TGHK map is presented in Figure 4 and the data is presented in Table 6. While sub-districts where there is not enough allocation of cultivation space for agriculture, available suitable land is used for agriculture.

Table 6 shows that based on the TGHK criteria, the cultivation area was only 119,907.37 ha (21.60\%). This area is actually up to the year of 2032 is still quite sufficient, because, in the year 2032, it requires only cultivation land of 89,772.48 ha. However an area of 119,907.37 ha is not evenly distributed, thus Blangkejeren, Puti Betung, and Blang Pegayon are not fulfilled. Table 13 shows that the cultivation area is only $23.95 \%$ different from the allocation of cultivation areas which is almost $29 \%$.

Land use is a basic aspect needed for any kinds of human activity, such as agriculture, industry, settlement, transportation, recreation or areas that are maintained by their natural conditions for scientific purposes such as protected forests and others [7]. The land is a natural resource that cannot be renewed, while the demand for land is always increasing. This is because the rate of the population continues to increase. Therefore, land use must refer to the allocation plan that has been set for each level [7]. The highest land use values are industrial and trade areas, followed by residential areas, agricultural land, and lastly uncultivated grazing and wildland [15]-[17].

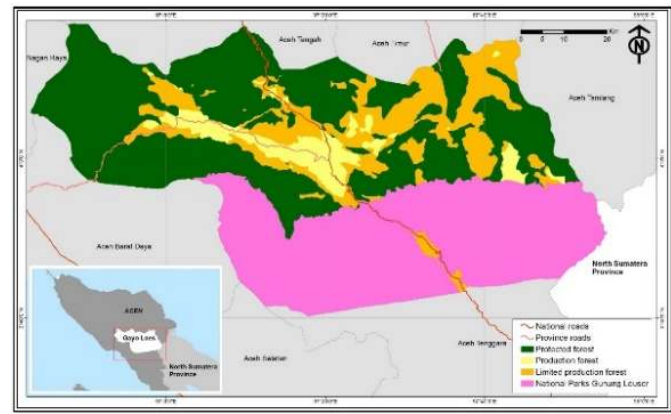

Figure 4. Map of the Agreeable forestry land (TGHK) of the Gayo Lues District

Table 6. Allocation of cultivation areas based on TGHK criteria

\begin{tabular}{|c|c|c|c|c|c|c|}
\hline \multirow{2}{*}{ No } & \multirow{2}{*}{ Sub-district } & \multicolumn{4}{|c|}{ Area Allocation (ha) } & \multirow[t]{2}{*}{$\begin{array}{c}\text { Total } \\
\text { (ha) }\end{array}$} \\
\hline & & LNP & PA & PF & LPF & \\
\hline 1. & Kuta Panjang & $17.594,26$ & $4.515,60$ & $3.459,21$ & $1.384,02$ & $26.953,09$ \\
\hline 2. & Blang Jerngo & $15.809,31$ & $11.045,08$ & $5.384,22$ & $6.008,10$ & $38.246,71$ \\
\hline 3. & Blangkejeren & $4.426,03$ & $4.718,29$ & $4.987,18$ & $2.474,49$ & $16.605,99$ \\
\hline 4. & Putri Betung & $96.645,15$ & 112,93 & 3,69 & $2.931,55$ & $99.693,32$ \\
\hline 5. & Dabun Gelang & $20.630,57$ & $12.412,05$ & $4.017,11$ & $7.412,30$ & $44.472,03$ \\
\hline 6. & Blang Pegayon & $17.917,07$ & $6.893,92$ & $1.345,57$ & $1.061,52$ & $27.218,08$ \\
\hline 7. & Pining & $28.660,47$ & $54.270,09$ & $6.427,61$ & $46.385,13$ & $135.743,30$ \\
\hline 8. & Rikit Gaib & - & $19.258,93$ & 312,92 & $6.851,48$ & $26.419,33$ \\
\hline 9. & Pantan Cuaca & - & $26.440,09$ & 878,04 & $2.228,31$ & $29.546,44$ \\
\hline 10. & Terangun & 112,48 & $56.196,92$ & $5.302,21$ & $4.781,62$ & $67.291,48$ \\
\hline \multirow[t]{3}{*}{11.} & Tripe Jaya & - & $37.449,55$ & $1.265,50$ & $5.020,19$ & $43.735,24$ \\
\hline & Total & $201.795,34$ & 233.313,35 & $33.368,66$ & $86.538,71$ & $555.016,06$ \\
\hline & Percentage & 36,36 & 42,20 & 6,01 & 15,59 & 100,00 \\
\hline
\end{tabular}

Source :Data Analyzed (2018)

Note* $: \mathrm{LNP}=$ Luser national park, $\mathrm{PA}=$ Protected forest/Area, $\mathrm{PF}=$ Production forest, dan

$\mathrm{LPF}=$ limited production forest 
Further detail analysis based Table 6, we found an area of 226,98 ha of Leuser national park is a cultivation area, and we also found an area of 50,430,800 ha of the protected forest is also the cultivation area. Therefore, an area of 50.657,78 ha of cultivation is declared as a noncultivation area.

We also found that irregularities in land use may be due to the allocation of space for cultivation areas that not fully meet the indicators of land potential. In addition, the allocation of space for cultivation areas has not met the needs of the farming community, especially not spread proportionally. If the Gayo Lues RTRWK can be revised, there are 50,657,78 ha an area of land within a protected area that can be used as a cultivation area. This condition can be done by exchanging land that has been allocated to the cultivation space but does not meet the TGHK criteria. There are an area of about 37,000 lands allocated for cultivation space but do not meet the criteria of TGHK as a cultivation area, namely production forests of around 7,000 ha and limited production forests of around 30,000 ha. The allocation of this area can be returned to its function as a non-cultivation area and land that meets the criteria for the cultivation of 50,000 ha which is currently in a protected area can be issued as a cultivation area.

\section{Conclusion and Recommendation}

1. Allocation of cultivation space that is provided until the year 2032 is 160,017 ha. In general, for districts, this area is sufficient for the population up to 2032 which increases at a rate of $1.69 \%$ per year. Based on the sub-district, this area is not well distributed so that there are three subdistricts not fulfilled, namely Blangkejeren, Blang Pegayon, and Putri Betung Sub-districts since 2016 and Kuta Panjang sub-district starting in 2020.

2. There has been a land use deviation of 1,482.30 ha. Land use deviations occur in all districts. The widest sub-district is Blangkejaren, Dabun Gelang, and Putri Betung. The deviation of land use is mainly used for the development of Sere Wangi commodities. There is around 37,000 ha of 160,017 ha of cultivation space allocation that cannot be used. Conversely, there is about 50,000 ha of land outside the allocation of cultivation space can be used for cultivation land.

To arrange the allocation of cultivation space so that there is no greater deviation, especially in Blangkejeren, Dabun Gelang, Putri Betung, Blang Pegayon, and Kuta Panjang Districts, it is recommended that this allocation of cultivation space be revised before 2032 .

\section{REFERENCES}

[1] Undang-Undang Republik Indonesia Nomor 26 Tahun 2007, Penataan ruang, vol. 136, no. 1. 2007, pp. 23-42.

[2] Qanun Aceh Nomor 19, Rencana tata ruang wilayah Aceh tahun 2013 - 2032. 2013.

[3] Qanun Kabupaten Gayo Lues Nomor 15, Rencana tata ruang wilayah kabupaten gayo lues tahun 2013 - 2032. 2013.

[4] Badan Pusat Statistik, "Gayo lues dalam angka," Kabupaten Gayo Lues, 2017. .

[5] Bappeda Gayo Lues, "Indikator ekonomi daerah kabupaten gayo lues. Kerjasama bappeda dengan unit pelatihan dan perencanaan pembangunan regional. Fakultas Ekonomi Universitas Syiah Kuala," 2014.

[6] SK Menteri Pertanian Nomor 837/Kpts/Um/11/1980, Kriteria dan tata cara penetapan hutan lindung. 1980, pp. 1-15.

[7] Bappeda Gayo Lues, "Revisi rencana tata ruang kabupaten gayo lues," Laporan Akhir, 2008. .

[8] Darwanto, "Mekanisme pengelolaan perencanaan tata ruang wilayah pesisir, laut dan pulau-pulau kecil serta hubungannya antar perencanaan yingkat kawasan kabupaten, provinsi, dan nasional," Jakarta, 2000.

[9] S. Budiharsono, Teknik analisis pembangunan wilayah pesisir dan lautan. Jakarta: Pradnya 
Paramita, 2002.

[10] O. Soemarwoto, "A qualitative of population pressure and it's potential use in development planning," Majalah Demografi Indones., vol. 12, no. 24, 1985.

[11] Suwandi, "Keberlanjutan usaha tani pola padi sawah-sapi potong terpadu di kabupaten sragen: Pendekatan RAP-CLS,” Tesis. Sekolah Pascasarjana IPB, Bogor., 2005.

[12] Wahyunto, M. Z. Abidin, A. Priyono, and Sunaryo, "Studi perubahan penggunaan lahan di sub das citarik, jawa barat dan das kaligarang, jawa tengah," in Prosiding Seminar Nasional Multifungsi Lahan Sawah, 2000, pp. 39-40.

[13] Firmansyah, "Identiflkasi resiko bencana gempa bumi dan implikasinya terhadap penataan ruang di kotamadya daerah bandung," Institut Teknologi Bandung, 1998.

[14] H. Haerumen, "Pedoman pengelolaan dan pengembangan lingkungan alam wilayah pesisir," Jakarta, 1996.

[15] M. Suparmoko, Ekonomi sumber daya alam dan lingkungan, 3rd ed. Yogyakarta: BPFE UGM, 1997.

[16] B. Irawan and S. Friyatno, "Dampak konversi lahan sawah di jawa terhadap produksi beras dan kebijakan pengendaliannya," J. Sos. Pertan. dan Agribisnis SOCA, pp. 1-33, 2002.

[17] I. G. N. Santosa, G. menaka Adnyana, and I. ketut K. Dinata, "Dampak alih fungsi lahan sawah terhadap ketahanan pangan beras," in Prosiding Seminar Nasional Budidaya Pertanian, 2011, pp. $1-11$. 